\title{
Bankruptcy Law of Share Companies under Ethiopian Law: Focus on Non-Financial Sectors
}

\author{
Yared Kefyalew Demarso, Bogale Anja Abba \\ School of Law, Wolaita Sodo University, Wolaita Sodo, Ethiopia \\ Email: yaredoo2@gmail.com,bogawassa@gmail.com
}

How to cite this paper: Demarso, Y. K., \& Abba, B. A. (2021). Bankruptcy Law of Share Companies under Ethiopian Law: Focus on Non-Financial Sectors. Beijing Law Review, 12, 250-265.

https://doi.org/10.4236/blr.2021.121015

Received: December 20, 2020

Accepted: March 28, 2021

Published: March 31, 2021

Copyright $\odot 2021$ by author(s) and Scientific Research Publishing Inc. This work is licensed under the Creative Commons Attribution International License (CC BY 4.0).

http://creativecommons.org/licenses/by/4.0/

\section{(c) (i) Open Access}

\begin{abstract}
This research has investigated the Ethiopian bankruptcy law governing share companies in light of the 2005 legislative guide of the United Nations. The research employed doctrinal legal research approach and those collected data were analyzed qualitatively. The Ethiopian bankruptcy law is also compared with the international guidelines. The bankruptcy law regulating business organizations in general and share companies in particular is in operation since 1960. However, it is considered to be one of the least practiced laws of the country due to the reasons, such as historical background, lack of familiarity and existence of foreclosure law. The paper addresses whether there is a need to amend the bankruptcy law of share companies engaged in non-financial businesses in Ethiopia. In particular, it is devoted to deal with the scope of liquidation, initiation of liquidation, actors in liquidation and effects of liquidation. It is still tried to investigate the gaps and areas which need revision in the current bankruptcy provisions of the 1960 commercial code of Ethiopia. It has been concluded that, the bankruptcy provisions which are applicable for share companies fail to satisfy the current sophisticated business environment. In addition to these, the provisions are not in line with the standards of the legislative guide with regard to the critical issues. Therefore, this paper suggests that there is a need to revise and modernize the bankruptcy provisions governing share companies other than financial institutions in the country taking the current business environment and standards of the legislative guide into consideration.
\end{abstract}

\section{Keywords}

Bankruptcy, Share Company, Commercial Code, UNCITRAL Legislative Guide

\section{Introduction}

It is common that business organizations enter into various transactions as a result of which one becomes a creditor and the other a debtor (Mitiku \& Ale- 
mayehu, 2009). The debtor may refuse or fail to pay the debt he owes from the creditor (Mitiku \& Alemayehu, 2009). In the modern time, this commercial relationship is regulated by using the bankruptcy law as a device (Mitiku \& Alemayehu, 2009). Bankruptcy is a statutory procedure by which a debtor obtains financial relief and undergoes a judicial supervised recognition of liquidation of the debtor's assets for the benefit of creditor (Getachew, 2009). So, bankruptcy law governs not only the rights of creditors, but also the rights of insolvent debtor.

The main objective of modern bankruptcy law is not limited in the protection of the rights of the creditor and the debtor, but also increases the overall economic efficiency by eliminating the functionally inefficient firms whose assets can be used in more productive way elsewhere (Meaza Ayalke, 2011). Among others, it is aimed to maximizing asset values, allocating risk among participants, encouraging investment risk taking, supporting wider community interests, and facilitating orderly market exit system (Meaza Ayalke, 2011). So, bankruptcy law of business organizations should be adopted taking these objectives into consideration.

Bankruptcy laws, particularly, regulating share companies need special attention in order to protect the rights of creditors as the liabilities of shareholders are limited. In other words, the rights of creditors may be exposed to high risk when a company becomes economically inefficient as members of a company are not personally liable for the debt of the firm. Due to the need to protect the rights of creditors, business organizations engaged in financial businesses have obligation to provide sufficient reserve funds in the regulatory body (i.e. central bank). There is no similar safeguard in case share companies other than financial institutions. The effect may not be as such rigorous in case of partnership as the liabilities of partners are not limited.

Bankruptcy laws were areas of law that received little attention for many years (Meaza Ayalke, 2011). Since initiation of revision of law arose from understanding the importance of that specific law, the Ethiopian bankruptcy law remained for numerous decades without amendment. It is the least known and hence least practiced law in Ethiopia (Lencho, 2008). It has remained static, contrary to observations by scholars that the law of insolvency has been in a state of flux (Meheret, 2017).

In Ethiopia, the first bankruptcy law was enacted during Emperor Haile Sellassie I on July 12, 1933 (Lencho, 2008). The law was adopted as a modern law in the area and contains 96 articles (Lencho, 2008). Under the 1933 bankruptcy law, "every person registered in the commercial register" and who suspends payment might be declared bankrupt (Article 1 of the Bankruptcy Code, 1933). The proceeding of bankruptcy begins by suspension of payment only when the obligation of payment arises out of what the law calls an "executory document". An executory document is defined narrowly and refers three documents. These are a judgment against the debtor in a court of last appeal; a minute of a concili- 
ation proceeding in which the debt is recognized without reservation; a commercial instrument signed or accepted by the debtor accompanied by a protest for non-payment regularly drawn up.

There were some distinct features of the 1933 bankruptcy law (Lencho, 2008). One of the main features of the law is that the commencement standard was very stringent. The law allowed initiation of bankruptcy only against debtors who suspended a payment which was a sum certain, liquid and in all respects evidenced by a written document. The other is the law did not have provisions for schemes of arrangement and it contained penal provisions.

The Commercial Code of Ethiopia (here in after called "the code") was enacted and came to effect on September 11, 1960 by repealing the previous bankruptcy law of 1933 (Lencho, 2008). The main source of the bankruptcy law of the code was the French bankruptcy law which provided two procedures namely bankruptcy and judicial administration (Lencho, 2008). However, the drafter of the code replaced the judicial administration procedures with the schemes of arrangement systems by using Italian law of 1942 as a source.

The bankruptcy provisions of the code came up with certain distinct structures (Lencho, 2008). Firstly, the structural arrangement of the bankruptcy law infers that the law prefers liquidation to rehabilitation of the debtor's business. This is concluded from the implied arrangement of the law as provisions of bankruptcy precede the provisions on composition and schemes of arrangement. Secondly, the largest number of provisions is devoted to the liquidation. The other is the code provided two procedures for debtors in financial difficulties. The debtor and other parties may either opt bankruptcy or schemes of arrangement and although there are possibilities for conversion from one proceeding to the other. Thirdly, the code follows a dual system of bankruptcy and schemes of arrangement, setting down separate rules in a separate title for business organizations.

Business organizations may either engage in financial or non-financial businesses. Financial businesses, among others, include banks, insurance and microfinance institutions. In Ethiopia, only share companies are allowed to engage in financial sectors and hence regulated by the special law. There are also share companies that engage in non-financial businesses. However, there is no special bankruptcy law governing share companies engaged in non-financial businesses.

\section{An Overview of Related Literature}

\subsection{Bankruptcy Law in General}

According to some writers, the term bankruptcy was derived from two French or Latin words. The first is "bancus" and "ruptus" which means table and broken respectively. So, literally speaking, bankruptcy is to mean broken table (Mitiku \& Alemayehu, 2009). Some other writers also said that the term first derived from the Italian word "bancorotto or bancarotta" which signified the medieval prac- 
tice of breaking tables/benches on a trader who absconded with the money or goods of creditor (Lencho, 2008). According to world encyclopedia bankruptcy is defined as "... the state of being legally unable to pay debts" (Getachew, 2009). The Black's law dictionary also defined bankruptcy as "a statutory procedure by which accused insolvent debtor obtains financial relief and under goes a judicial supervised recognition of liquidation of the debtor's assets for the benefit of creditor (Getachew, 2009).

The term bankruptcy is used only for individual debtor's insolvency whereas the term liquidation is used for insolvency of business organization according to some writers (Mitiku \& Alemayehu, 2009). However, many jurisdictions use the term bankruptcy interchangeably with insolvency and sometimes use bankruptcy as general term applied for both natural and legal persons (Mitiku \& Alemayehu, 2009). The code consistently uses the term bankruptcy in all but one provision, while almost all the other codes like the Maritime Code of Ethiopia (Article 299(1) of the Maritime Code of Empire of Ethiopia, 1960) employ both terms (Meheret, 2017). But both terms seems to be used interchangeably under article 542(3) of the code and articles 15(2) (b), 28, 42(d), 54 and 55 of the Civil Procedure Code of Ethiopia. The two terms appear to connote indebtedness and status under the Civil Code of Ethiopia (Articles 1145, 1932, 2000, 1947, and 2697(3) of the Civil Code, 1960). For example, the insolvency of an association or an endowment can be a ground for the dissolution of an association or the termination of endowment; issues beyond the scope of the bankruptcy regime of Ethiopia (Article 461(d) of the Civil Code of Empire of Ethiopia, 1960). So, the Civil Code uses term insolvency to refer the factual situation without judgment by a court to ascertain the fact. The Criminal Code of Ethiopia makes the same distinction between the two terms (Articles 725 and 727 of the Criminal Code of the Federal Democratic Republic of Ethiopia, FDRE, 2004).

Despite in the absence of clear distinction, the term insolvency used to refer the inability of a debtor to pay debts which are due, whether or not the debtor is a trader and whether or not the debt is commercial (Meheret, 2017). The term bankruptcy, on the other hand presupposes the existence of court judgment that recognizes the fact of the financial distress of a business organization (Meheret, 2017). To be bankrupt, the debtor should be a trader or commercial business organization and there should be a court decision.

The Banking Business Proclamation of Ethiopia uses the term "receivership" instead of bankruptcy to denote corrective measures to be taken, including liquidation (Meheret, 2017). The Insurance Proclamation of Ethiopia also employed the same terminology (Article 37 of the Insurance Business Proclamation). It defines the term insolvent as the financial condition of a bank when its liabilities exceed its assets as determined by the National Bank of Ethiopia (Article 2(12) of Banking Business Proclamation of the Federal Democratic Republic of Ethiopia, FDRE, 2008). Under this proclamation, unlike the code, the date of commencement used to determine insolvency of a bank and the insolvency of 
a bank is only determined by the National Bank of Ethiopia, not the ordinary court (Meheret, 2017).

\subsection{Overview of Share Company}

According to the constitution of Ethiopia, every person has the right to freedom of association for any cause or purpose (Article 31 of the FDRE Constitution, 1995). The constitution guarantees the right to freedom of association for any purpose including for commercial or business purpose. So, the right to form association is constitutionally guaranteed right. It only prohibits organizations formed by violating laws, to subvert the constitutional order or which promote such activities (Article 31 of the Constitution of the Federal Democratic Republic of Ethiopia, FDRE, 1995).

The term "company" is used in the Ethiopian legal system while the term corporation is used in the common law legal system though it is broader in concept which includes public enterprises (Endalem Lijalem, 2012). The term company defined as a voluntary association of persons formed to achieve some common objectives, having a separate legal entity, independent and separate from its members, with a perpetual succession and a common seal, and with capital divisible into transferable shares (Endalem Lijalem, 2012). Another comprehensive and clear definition of a company is given by Lord Justice Lindley, "A company is meant an association of many persons who contribute money or money's worth to a common stock and employs it in some trade or business, and who share the profit and loss (as the case may be) arising there from". There is no definition for the term company under the Ethiopian law but it is understood by its attributes like separate legal personality, limited liability of shareholders (Endalem Lijalem, 2012).

There are two types of companies under the Ethiopian law namely private limited company and a share company. Private limited company is a company whose members are liable only to the extent of their contributions, its members should not be less than two and not more than fifty members and always commercial in nature (Commercial Code of Empire of Ethiopia, 1960). This type of company shares both features of partnerships and share companies. That is why it is always regarded as hybrid form of business organizations. It is prohibited for private limited company to engage in financial business activities like banking, insurance and microfinance business. A share company, on the other hand, is a company whose capital is fixed in advance and divided into shares which collected through public subscription and whose liabilities are only met by the assets of the company (Commercial Code, 1960). To form a share company, its capital should be fully paid up and at least one fourth of its capital should be paid up (Commercial Code, 1960). The minimum number of members is five and there is no maximum limit of members. Unlike private limited company, there is also no limit as to the kind of business activity that a share company may engage in. 


\section{Bankruptcy Law of Share Companies Engaged in Non-Financial Sectors under Ethiopian Law and the UNCITRAL Guideline}

In Ethiopia, share companies are governed by the commercial code of the 1960 and other specific legislations. However, the code is not applicable for bankruptcy of financial institutions as they are governed by separate laws. The financial institutions such as banks, insurances and microfinance institutions are operated by share companies but they are governed by separate legislations. For example, banking and insurance businesses are governed by the Banking Business Proclamation of the Federal Democratic Republic of Ethiopia, FDRE, 2008 and Insurance Business Proclamation of the Federal Democratic Republic of Ethiopia, FDRE, 2012 respectively. Microfinance institutions are also governed by the microfinance business proclamation no. 626/2009 and its amendment proclamation no. 1164/2019. Besides these, there are various specific directives which regulate financial institutions issued by the National Bank of Ethiopia. These specific laws, in addition to the general provisions of the code, apply to share companies engaged in financial institutions (Tura, 2012).

Since the liability of members of share company is limited, the debt of the company only covered from the assets of the company. In other words, shareholders are not liable for the debt of the company. Due to this, the right of the creditors of a share company may be easily affected unless the company has sufficient asset to cover the debt. In order to avoid or reduce such problems, there are special bankruptcy laws enacted for share companies engaged in financial businesses. Despite the fact that financial institutions are share companies, their bankruptcy issues are regulated by special laws. However, there is no similar law which governs share companies which are engaged in non-financial sector. So, creditor of a share company engaged in financial institution and creditor of a share company engaged in non-financial businesses are not treated equally. This in turn reduces the confidence of creditors of non-financial business organizations.

The scope of bankruptcy law covers the subjects of bankruptcy proceedings. Historically, bankruptcy law applies to persons who were involved in commercial activities but later, due to Spanish law influence, persons who engage in non-commercial activities were made subjects of bankruptcy law. According to the provisions of Book V of the commercial code of Ethiopia, bankruptcy and schemes of arrangement applies to traders and any commercial business organizations within the meaning of article 10 of the same code except joint venture (Article 968 of the Commercial Code of Empire of Ethiopia, 1960).

The commercial nature of business organizations may be inferred either from the objects under the memorandum of association or the activities carried out by the business organizations under article 5 of the code (Article 10 of the Commercial Code of Empire of Ethiopia, 1960). In addition to these, the form of the business organization helps to determine its commercial nature as private limited company and share companies are always presumed commercial only 
based on their form (Article 10 of the Commercial Code of Empire of Ethiopia, 1960). In other words, a private limited company or share company is always presumed commercial for whatever purpose they are formed. Since both types of companies are always presumed as commercial, they are subject to bankruptcy provisions of the code (Article 10(2) of the Commercial Code of Empire of Ethiopia, 1960). Only commercial business organizations, except joint venture, may be adjudged bankrupt or be granted a scheme of arrangement (Article 1155(1) of the Commercial Code of Empire of Ethiopia, 1960). Article 968(1) of the Code clearly excludes non-commercial business organizations from application of bankruptcy law, however, if engaged in activities under article 5 of the code, can be considered for application of bankruptcy law. Accordingly, even if an ordinary partnership is not a commercial business organization within the meaning of article 213 of the code, it is the subject to bankruptcy proceeding as per the provisions of article 968 of the same code. Therefore, which rules apply to non-commercial business organizations is the question not addressed by the code.

Commencement standards or conditions of initiation of bankruptcy proceedings are among the central issues of bankruptcy law. It identifies the debtors who are important protective and disciplinary concerns of bankruptcy law and who may make an application for commencement. The UNCITRAL legislative guide (hereinafter called "the legislative guide") provides for general principle that the commencement standard should be transparent and certain, facilitating access to insolvency proceedings conveniently, cost-effectively and quickly to encourage financially distressed or insolvent business to voluntarily commence proceedings. Flexible access in terms of the types of insolvency proceedings available (reorganization and liquidation), and the ease with which the proceeding most relevant to a particular debtor can be accessed, and that conversion between different types of proceedings can be achieved are another standards under the guideline. The two commencement standards under the guideline are namely the cash flow method where the debtor is or will be generally unable to pay its debts as they mature and the balance sheet method where the liability of debtor exceeds the value of its assets.

There are persons who are specifically authorized to initiate the bankruptcy proceeding. The debtor, one or more creditors, the public prosecutor or the court itself are parties authorized to initiate bankruptcy proceeding (Article 975 of the Commercial Code of Empire of Ethiopia, 1960). The provisions under Titles I, II, III, and V of Book V of the code apply to both traders and commercial business organizations and Title IV of the same book only apply to business organizations (Article 968(2) of the Commercial Code of Empire of Ethiopia, 1960). Accordingly, notice of suspension of payments by a business organization may be made by its legal representatives and, in the case of a firm in liquidation, by the liquidator (Article 1156 of the Commercial Code of Empire of Ethiopia, 1960). So, no one is allowed to initiate the bankruptcy proceeding except those 
persons authorized for such purpose.

In Ethiopia, there are two conditions for commencement of bankruptcy. These are suspension of payment by a trader and declaration of bankruptcy (Articles 969 and 970(1) of the Commercial Code of Empire of Ethiopia, 1960). In other words, the mere fact of suspension of payments does not result in bankruptcy. If it is solely suspension of payment, it is taken as bankruptcy in fact (Lencho, 2008). So, a court declaration is required in addition to suspension of payments. Only a court having jurisdiction can give decision of bankruptcy (Lencho, 2008). That is why bankruptcy has far-reaching legal and factual consequences up on the business of the debtor and the cumulative requirement should met in order to protect the rights and interests of the debtor (Lencho, 2008).

\subsection{Actors in Bankruptcy}

Bankruptcy proceeding requires involvement of different persons or institutions. There are several persons who are responsible for conducting bankruptcy proceeding until closure or discharge of the bankrupt debtor. These organs responsible to accomplish the dominant role in the bankruptcy proceeding are the court, commissioner, trustees and creditors committee (Articles 989-1003 of the Commercial Code, 1960). They have their own responsibilities on the administration of bankruptcy proceeding specially on the distribution of assets of the debtor. In this regard, the code clearly describes different organs for the distribution of debtor's estate on the similar fashion provided under the legislative guideline. In addition to these actors, persons such as the judge (article 976 (1)), the public prosecutor (article 1017), the bankrupt debtor (articles 1021 and 1024), the receiver (article 1039(3)), competent authorities (article 991(3)) and individual creditors (articles 1041-1046 and 1082-1085) play their own role in the bankruptcy proceedings according to the code.

\section{1) Court}

Court of bankruptcy is a judicial body which declares the debtor bankrupt. The court which found on the place where the head office of the business organization situates has jurisdiction in bankruptcy proceedings (Article 1157 of the Commercial Code, 1960). The court plays its roles like control and supervision. It also gives decisions on matters which are outside the power of the commissioner and entertain appeals from order of the commissioner (Article 989 of the Commercial Code, 1960). Besides, the court may replace the commissioner at any time by its own motion (Article 993 of the Commercial Code, 1960). Moreover, it renders the last decision in overall issues in connection with the bankruptcy proceeding and hieratically stands at the top of all responsible persons in the proceeding.

\section{2) Commissioner}

There is no definition given for the word commissioner in the code. However, it is assigned to play some responsibilities in a bankruptcy proceeding. Accord- 
ing to article 991 of the code, the commissioner is responsible to:

- supervise and deal with all matters concerning the bankrupt estate;

- refer claims to the court and authorize the trustee to enter appearance in legal proceedings;

- take or cause to be taken by the competent authorities all steps and measures necessary to preserve the assets;

- authorize the trustee to appoint assistant; and

- call creditors committee as required by law or where he considers to be necessary.

In addition to these, the commissioner may apply to court to appoint additional trustees or to replace existing trustees (Article 999 of the Commercial Code, 1960).

\section{3) Trustees}

Trustees are persons responsible for administering day-to-day activities of bankruptcy proceeding. To be appointed as a trustee, a person must be resident in Ethiopia and a person with good reputation. He/she should be reliable person to deal with such a responsibility. Trustees have given various names in different legal systems such as administrator, liquidator, supervisor, curator, receiver, official, judicial manager, or commissioner. For instance, the banking business proclamation of Ethiopia has employed the term "receiver" instead of "trustee" (Article 33 of the Banking Business Proclamation of the Federal Democratic Republic of Ethiopia, FDRE, 2008).

The legislative guideline, on the other hand, employed the phrase "insolvency representative" in broad manner to refer a person or legal entity who accomplishes such duty (Part II article 35 of the legislative guideline, 2005). The insolvency representative is required to possess knowledge, experience, and personal qualities that will ensure effective and efficient conduct of the proceeding and hence to build confidence in the insolvency regime. The guideline also requires the trustee to be free from conflict of interest (i.e. independence from vested interests of an economic, familial or other nature) (Part two article 42 of the legislative guideline, 2005).

Even though the code does not list qualities that the trustee must fulfill, it provides some exclusion. Persons who have been declared bankrupt; persons who deprived of their civil rights; and persons who are related with debtor either by consanguinity or affinity, and creditors of the debtor do not qualify for appointment of trustee because they lack integrity (Article 994(4) of the Commercial Code of Empire of Ethiopia, 1960). The trustees must accomplish his duties such as depositing funds of the debtor, represent the universalities of creditors, administer the bankrupt estate in due care and in person (Article 995(1) of the Commercial Code, 1960). They are, on the other land, entitled to some rights like remuneration (Article 1001 of the Commercial Code of Empire of Ethiopia, 1960).

\section{4) Creditors' Committee}


They are also known as "bankruptcy controllers" or simply "controllers". The main role of creditors committee is facilitating creditor's participation in bankruptcy proceedings. The guideline states that appointment of creditors committee is not necessary in all insolvency cases (Part two article 99 of the legislative guideline, 2005). It may be appointed where necessary for instance, where there are very large numbers of creditors, or where they have diverse interest, or such an appointment is desirable based on the feature of the case (Part two article 99 of the legislative guideline, 2005). Some jurisdictions give discretions to creditors to appoint or not the representative while in some other jurisdictions courts appoint it. In case of Ethiopia, the code, however, does not provide the exceptional situations where creditors' committees are not necessary. The number of creditors' committee members selected by the commissioner must be three to five (Article 1002(3) of the Commercial Code of Empire of Ethiopia, 1960).

The selection criteria of members of creditors committee vary from one jurisdiction to another. Some jurisdictions restrict membership to creditors whose claims are verified and admitted. Some others restrict based on location of creditors while still others permit formation of separate committee for different categories of creditors. In case of Ethiopia, they are chosen from among all the creditors and not entitled to payment of remuneration (Article 1002(3) and (7) of the Commercial Code of Empire of Ethiopia, 1960). The creditors committee plays its own role in the bankruptcy proceeding. Their role may be divided into advisory, control and decisive functions (Article 1003 of the Commercial Code of Empire of Ethiopia, 1960). These include:

- advising a trustee of the wishes of the creditors in relation to issues like sale of business assets outside the ordinary course of business;

- Verification of the accounts and statements of affairs prepared by the debtor and to the supervision of the acts of the trustees;

- Requesting information on the state of the bankruptcy proceeding and on the position of receipts and payments; and

- Consulted by the trustees regarding legal proceedings.

\subsection{Effects of Bankruptcy}

Bankruptcy proceeding can affect different parties such as the debtor, creditors, and third parties. It may have an effect on personal and pecuniary matters of the debtor. It is difficult to apply directly some personal effects of bankruptcy stipulated in the commercial code in case of bankruptcy of business organizations. The bankruptcy of a share company cannot automatically cause the bankruptcy of the shareholders or managers. However, any person who has carried out commercial operations on his own behalf and disposed of company funds as though they were his own and concealed his activities under the cover of such company becomes bankrupt where the company declared bankrupt (Article 1160(1) of the Commercial Code of Empire of Ethiopia, 1960).

Once judgment of bankruptcy has been declared, the debtor should not admi- 
nister or dispose of his property (Article 1023 of the Commercial Code of Empire of Ethiopia, 1960). The code does not provide that against whom such a dispossession can be effected in the case of bankruptcy of business organization. In other words, the code does not separately deal about the issue of dispossession where business organizations become bankrupt. Here the necessity of dispossession is under question because persons who run the organization are not really the debtors. It is not explicitly provided in the code that whether dispossession should be effected against managers or members of board of directors. It does not create any problem in case of bankruptcy of partnership because bankruptcy of partnership automatically results in bankruptcy of the general partners. In this case, the trustees will be empowered for the administration of the estate. However, avoiding managers or board of directors from their power is difficult in the case of bankruptcy of company unless the court orders to do so. If the court in the judgment of bankruptcy is silent about the management of bankrupt company, it is difficult for trustee to take over the management. Even the expectation that the court can give such an order is also questionable. This problem is the result of dual organization of bankruptcy law by providing distinct rules for business organization.

Bankruptcy proceeding also affects the rights of the creditors. Some of the following are among such effects. These are:

- Restriction on separate claims: creditor's right to lodge individual claims against the debtor is restricted and universality of creditors which is a legal entity instead created (Article 1025 of the Commercial Code of Empire of Ethiopia, 1960);

- Suspension of all suits by creditors except secured creditors (Article 1026 of the Commercial Code of Empire of Ethiopia, 1960). It is also known as "stay" or "moratorium" based on the effect of the mechanism.

According to the legislative guide, one of the main objectives of bankruptcy is maximizing the value of estate of the bankrupt debtor. Suspension of individual actions helps to achieve fair and orderly administration of the proceeding, and not to come up with result which is prejudicial to both debtors and creditors. As pointed out in the legislative guide, some laws suspend all administrative, judicial or self-help remedies and proceeding against the debtor. Some others limit actions that may be continued and allow initiation of certain actions. Still some others allow initiation and continuation of certain actions but prohibit execution of judgment or orders. Others allow regulatory action to continue but not the pecuniary actions.

\section{1) Distribution}

Distribution of the estate of a debtor is taken as the outcome of financial distress. It is the conversion in cash or sale of a firms or a certain individual asset. The sale of assets may include a going concern bases which involve the sale of the entire business including good will or a break up bases where by the assets are sold gradually. The primary goal of bankruptcy law is enhancement of effi- 
ciency by improving the value of the estates of distressed debtor and reducing the possible costs. It is an efficient closure of the procedure of liquidation and transfer of a business which is at financial crises.

The code provides method of distribution of the estates of bankrupt debtor. It states that distribution of assets should be made to creditor in proportion to their claim after cost and expenses for the liquidation, sums applied for the support of the debtors or his family and sums paid to preferred creditors are paid (Article 1110 of the Commercial Code of Empire of Ethiopia, 1960). Concerning distribution of debtor's asset, the code has a problem with distribution regarding the issue of priority. The code does not make clear distinction between two or more preferential creditors. Normally, creditors to the bankrupt debtor are heterogeneous in nature. They have different claims emanated from different legal transactions. On the other hand, within a single bankruptcy case, there might exist many preferential creditors. For instance, competition for priority may arise between tax authority and employees payment. The code also does not solve the problem of priority between costs listed under sub article $\mathrm{a}, \mathrm{b}$ and $\mathrm{c}$ of article 1110 of the code. It does not answer the question of which of the three should come first. Even though costs and expenses are listed first, it seems as it is made for simple arrangement and not for priority purpose.

The legislative guide, on the other hand, recognizes the importance of prioritizing claims while distributing the debtor's asset (Part two article 51 of the legislative guideline, 2005). Accordingly, insolvency law ranks creditors for the purpose of distribution. The ranking may be made based on commercial recognition of important public areas or employment remuneration and insolvency administration costs. The guideline requires all legal systems to provide list of orders as to how distribution of estates of the debtor is made. They are under obligation to establish their bankruptcy law on the manner to include the way how payment of claims' should be prioritized among heterogeneous creditors mostly based on the nature of claims.

\section{2) Closure}

This is a stage where bankruptcy proceeding come to an end. After distribution of the all available assets of the debtor to creditors based on their sequence the proceeding of bankruptcy, it shall be closed and those organs that were facilitating the proceeding shall be relinquished from such duty. Different legal systems may follow different approach in order to declare closure. Some may close it when contractual agreement is made between debtor and creditors. This is the way of distribution of the estate of the debtor by mutual agreement. They may agree ordering payment of one creditor after other creditors' are fully paid. Some other laws require the formal application to court for an order of closure

The Ethiopian bankruptcy law provide different grounds for the closure of bankruptcy proceeding. The code it mentions three conditions for closure (Article 1113 of the Commercial Code of Empire of Ethiopia, 1960). These are the distribution of assets, insufficiency of assets and absence of claims against the 
bankrupt's estate. According to the legislative guideline, legal systems may follow different approach as to closure. The generally agreeable way of closure is made following the realization and asset distribution on the presence of insolvency representative and creditors by final accounting (if they agree on the accounting). As far as closure is concerned, the code and the guide take similar position. They both legalize the closure of the bankruptcy procedure which is made before the organ that is responsible for the entire procedure. Their difference is under Ethiopian bankruptcy law the closure is made by the court either by its own motion or by the report of the commissioner whereas the guideline accepts closure made by the insolvency representative as a final.

\section{3) Discharge}

Following the distribution of the estate of insolvent debtor, there are the possibilities that a number of creditors may not be paid in full. They might still remain unpaid mostly because of insufficiency of assets of the debtor. Business failure is a natural phenomenon of economy. Both weak and good business may fail without any negligence act on the part of the managers or the owner. People who have failed on a business may have learnt and get detail experience and may get successful in subsequent business.

The position of Ethiopian bankruptcy law concerning discharge is vague. It is not possible to confidentially argue about the existence or non-existence of discharge under Ethiopian law. This happens precisely because of the conflicting provision of the code. The code under closure of the proceeding clearly mentions different ground for closure but it keep silent about the fate of unpaid creditors' after closing of bankruptcy proceeding. The proceedings of bankruptcy may be closed when there is no sufficient asset to satisfy the debt (Article 1113(b) of the Commercial Code of Empire of Ethiopia, 1960). It does not answer weather creditors can activate their claim in future, if the debtor gets the capacity to pay his debt. Even it does not put any conditions referring the discharge.

On the other hand, the code provides list of conditions that cannot be a ground of appeal against preliminary decisions (Article 987(1) (b) of the Commercial Code of Empire of Ethiopia, 1960). Among this nobody can appeal on the order of discharge. The law puts the period in which the debtor will be dispossessed from the administration of his property (Article 1023 of the Commercial Code of Empire of Ethiopia, 1960). According to this article, the debtor prevented from the management of his property starting from the date of bankruptcy up to the date of discharge. From the readings of the two provisions, it is possible to conclude that there is a wide opportunity for the debtor to be discharged from his debt totally. The position of the guideline regarding discharge of the debtor is not as such clear. But it tries to strike a balance between the legitimate right of creditors and the fate of honest debtors. It intends to make the debtor totally free after declaration of bankruptcy in some conditions. Especially when the debtor is cooperative on the proceedings, in good faith or no fraud on 
his part and he is honest, it should be relieved from his debt and no creditors could claim the unpaid debt in the future time.

\section{Finding of the Research}

The following are the main findings of the research. The bankruptcy of share companies engaged in non-financial businesses is regulated by the bankruptcy provisions of the 1960 commercial code of Ethiopia. However, the code has applied without amendment for several decades and hence fails to satisfy the contemporary business environment. So, the law needs amendment in order to satisfy the modern business environment. In addition to these, there is a need to consider the international legislative guideline.

The code is failed to employ terms uniformly. For example, the code employed the term bankruptcy and insolvency for the same concept. In order to enjoy the advantages of rehabilitation, a bankruptcy law is advised to prefer rehabilitation instead of liquidation. However, the code is failed to prefer rehabilitation instead of liquidation as the structural arrangement of the bankruptcy provisions are not arranged in a manner that prefers rehabilitation to liquidation of the debtor's business. In addition to these, there is no special bankruptcy law specifically applicable for share companies engaged in non-financial sectors.

The bankruptcy provisions of the code also fail to exhaustively exclude some persons who may have conflict of interest from being appointed as a trustee. For example, persons who have prior or existing business relationship, prior ownership of the debtor, persons related with creditors of the debtor, prior relation with the debtor as a representative or officer of the debtor or relationship with the judge of court of bankruptcy are not excluded. In addition, the code does not provide that against whom such a dispossession can be effected in the case of bankruptcy of business organization. The list of some claims and costs is not detail and unequivocal and it may cause competition between and among preferred claims and costs. There is also unclear point on the issue of two or more preferential creditors. Therefore, there are no rank creditors and costs for the purpose of distribution as opposed to the legislative guideline.

\section{Concluding Remarks}

Currently, the bankruptcy of business organizations in general and share companies in particular are regulated by the bankruptcy provisions of the 1960 commercial code of Ethiopia. Since the code served for several decades without amendment, it fails to satisfy the current needs of the business environment. So, the law needs amendment and modernization taking the current business environment and the international legislative guideline into consideration. The following issues, among others, should be considered during amendment of bankruptcy provisions of the code.

Concerning the terminology, the code has employed both bankruptcy and insolvency for the same concept. So, the amendment of the code should use either 
bankruptcy or insolvency throughout the bankruptcy law uniformly. Besides this, there should be clear bankruptcy rules which are applicable for non-commercial business organizations. Structurally, the code gives priority for liquidation than rehabilitation of the debtor. The structural arrangement of the bankruptcy law should be arranged in a manner that prefers rehabilitation to liquidation of the debtor's business in order to enjoy the advantages of rehabilitation. Despite the existence of peculiar features of share companies, the code also fails to provide special provisions for bankruptcy of share companies. There are no special rules regarding bankruptcy of share companies which takes the rights of creditors into consideration as the shareholders have limited liability. So, there should be special laws specifically applicable for share companies engaged in non-financial sectors.

Since the code does not provide requirements to be a trustee that will ensure effective and efficient conduct of the proceeding, it needs amendment and hence to build confidence in the insolvency regime. The code fails to exhaustively exclude some persons who may have conflict of interest from being appointed as a trustee. The amendment should also exclude persons who have prior or existing business relationship, prior ownership of the debtor, persons related with creditors of the debtor, prior relation with the debtor as a representative or officer of the debtor or relationship with the judge of court of bankruptcy from being appointed as a trustee.

In addition, the code does not provide that against whom such a dispossession can be effected in the case of bankruptcy of business organization. It is not clear in this issue and creates difficulty in the implementation of the law. So, it needs to explicitly provide whether dispossession should be effected against managers or members of board of directors.

Despite the existence of list of some claims and costs that should be satisfied before the other, the listing is not detail and unequivocal and hence it is cause for competition between and among preferred claims and costs. Even it is said that the order is based on priority, there is also unclear point on the issue of two or more preferential creditors'. Therefore, it is strongly recommended that the amendment of Ethiopian bankruptcy law should come up with a list of creditors' and costs that have priority during distribution of assets in order to easy distribute the estates of the debtor in an orderly manner. Therefore, the amendment of the code needs to rank creditors and costs for the purpose of distribution as provided under the legislative guideline. The mere revision of law is nothing unless there is effective enforcement of law. Besides revision of the law, there is a need to conduct awareness creation and supervise effective implementation of the law.

\section{Conflicts of Interest}

The authors declare no conflicts of interest regarding the publication of this paper. 


\section{References}

Banking Business Proclamation of the Federal Democratic Republic of Ethiopia, FDRE (2008). Federal Democratic Republic of Ethiopia, Proclamation No. 592/2008. Addis Ababa: Banking Business Proclamation of the Federal Democratic Republic of Ethiopia.

Civil Code of Empire of Ethiopia (1960). Civil Code Ethiopia, Proclamation No. 165/1960. Addis Ababa.

Commercial Code of Empire of Ethiopia (1960). Commercial Code Ethiopia, Proclamation No. 166/1960. Addis Ababa.

Constitution of the Federal Democratic Republic of Ethiopia, FDRE (1995). Federal Democratic Republic of Ethiopia, Proclamation No. 1/1995. Addis Ababa.

Criminal Code of the Federal Democratic Republic of Ethiopia, FDRE (2004). Federal Democratic Republic of Ethiopia, Proclamation No. 414/2004. Addis Ababa: Criminal Code of the Federal Democratic Republic of Ethiopia.

Endalem Lijalem, E. (2012). The Doctrine of Piercing the Corporate Veil: Its Legal and Judicial Recognition in Ethiopia. Mizan Law Review, 6, 77-114. https://doi.org/10.4314/mlr.v6i1.3

Getachew, T. (2009). Legal Regime Bankruptcy of Bank under Ethiopian Law. LL.B Thesis, Addis Ababa: St' Marry University College. (Unpublished)

Insurance Business Proclamation of the Federal Democratic Republic of Ethiopia, FDRE (2012). Federal Democratic Republic of Ethiopia, Proclamation No. 746/2012. Addis Ababa: Insurance Business Proclamation of the Federal Democratic Republic of Ethiopia.

Lencho, T. (2008). Ethiopian Bankruptcy Law: A Commentary (Part 1). http://Chilot.wordpres.com

Maritime Code of Empire of Ethiopia (1960). Maritime Code Ethiopia, Proclamation No. 164/1960. Addis Ababa.

Meaza Ayalke, D. (2011). The Ethiopian Law of Bankruptcy: Its Shortcomings in Comparison to Modern Laws of Bankruptcy and Areas of Concern for Its Revision. MA Thesis, Addis Ababa: Addis Ababa University.

Meheret, T. (2017). An Appraisal of the Ethiopian Bankruptcy Regime. De Jure Law Journal, 50, 111-135. https://doi.org/10.17159/2225-7160/2017/v50n1a7

Mitiku, M., \& Alemayehu, T. (2009). Bankruptcy Law Teaching Material. Addis Ababa: Justice and Legal Research Institute. (Unpublished)

Tura, H. (2012). Overview of Corporate Governance in Ethiopia: The Role, Composition and Remuneration of Boards of Directors in a Share Companies. Mizan Law Review, 6, 45-76. https://www.researchgate.net/publication/312587074

https://doi.org/10.4314/mlr.v6i1.2 